\title{
Social tjänst till salu
}

\section{Om socialt arbete $i$ upphandlingens tid}

\begin{abstract}
Social service for sale. On social work in times of procurement
Market reforms within the Swedish welfare sector have paved the way for models based on buying and selling welfare services. Public procurement constitutes a hub for commissioning and providing social services. The aim of this article is to explore how social work is shaped within a procurement context. Attention is directed to how social workers providing procured services describe their work. The empirical material consists of interviews with 16 providers of social services within different areas of a procured social work. The results show how procurement shapes the provision of social work, in terms of specifications of time and quantity, a quantification of the work performed with clients and how the framework of procurement shapes the client as a commission and a case. It is further shown how providers compensate for and deal with the framework of procured social work to meet the clients' needs. The results raise questions about the possibilities for procured social work regarding the services' demarcation, specialisation, and time frame.
\end{abstract}

Keywords: social work, social services, public procurement, market, provider

DET FINNS I dag en omfattande litteratur som beskriver en gradvis marknadsorientering av den svenska välfärdsstaten (se t.ex. Rönnberg, Strandberg, Wihlborg m.fl. 2013). Inom en rad välfärdsområden har nyliberala ideal kunnat påvisats, där en marknadsvokabulär med fokus på effektivitet, konkurrens och valfrihet kommit att bli alltmer tongivande (Boréus 1994; Larsson, Letell \& Thörn 2012). I och med denna omvandling har strukturella insatser riktade mot kollektivet, med ambitioner om omfördelning av resurser och social förändring, gradvis ersatts av insatser riktade mot den enskilda individen, med ambitioner att värna individens valfrihet och ansvarstagande (Garsten \& Jacobsson 2004; Ruthström \& Svärdman 2011).

Spåren av denna marknadsorientering kan inte minst skönjas inom det sociala arbetet, exempelvis genom införande av beställar- och utförarmodeller i form av entreprenad och kundval (Hartman 2011; Szebehely 2011; Wiklund 2011) och en alltmer långtgående individualisering av insatser, med betoning på den enskilda klientens eget ansvar (Härnbro 2019; Jönsson 2019; Lauri 2019). Med denna pågående individualisering har det sociala arbetet i allt högre utsträckning kommit att formas utifrån ett ekonomiskt och mätbart raster, med större fokus på effektivitet och att uppnå mätbara 
resultat (Martinell Barfoed 2014; Chandler, Bell, Berg m.fl. 2015), samtidigt som strukturella insatser med mer långsiktig, och inte alltid uppenbart mätbar, effekt alltmer hamnat i skymundan (Bečević 2015; Dahlstedt \& Lalander 2018; Lindahl 2019).

I denna artikel vill vi uppmärksamma en del av denna marknadsorientering som inte rönt lika stor uppmärksamhet, nämligen upphandling. Mer specifikt vill vi bidra till en mer fördjupad kunskap om vad upphandling innebär för utförandeledet inom det sociala arbetet. Upphandling har under det senaste decenniet blivit en viktig del av hur offentliga verksamheter och tjänster organiseras samt utförs (Andersson, Erlandsson \& Sundström 2017; Holmqvist, Fejes \& Nylander 2021) och fått ett brett genomslag även inom det sociala arbetet och dess olika verksamhetsområden (Höjer \& Forkby 2011; Moberg 2017; Sallnäs \& Wiklund 2018). Genom upphandling skapas ett utbud av metoder och tjänster, som är tänkta att på ett effektivt och ändamålsenligt sätt möta klienternas behov (Barraket, Keast \& Furneaux 2015). Genom upphandlingsförfarandet specificeras vilka metoder och tjänster som efterfrågas, krav på kunskaper och kvalitet i genomförandet samt hur dessa krav kommer att följas upp. I upphandlingsförfarandet anges och formas vilket socialt arbete som är tänkt att utföras, hur och av vem. Därför kommer vi i denna artikel att fokusera på utförarsidan.

I upphandlingsförfarandet konkurrerar olika aktörer och därmed formas ett utbud av utförare, metoder och tjänster som det sociala arbetets praktik förväntas leverera (Forkby \& Höjer 2008; Hartman 2011). Tidigare forskning har pekat på framväxten av en marknad för socialt arbete inom områden som missbruksvård (Stenius \& Storbjörk 2020), äldreomsorg (Almquist \& Högberg 2008; Stolt, Blomqvist \& Winblad 2011; Moberg 2017) samt barn- och ungdomsvård (Wiklund 2005; Forkby \& Höjer 2008). I upphandling köps och säljs kunskap, som specificeras i krav på kompetens, utbildning och arbetsmetoder (Lindahl Toftegaard 2018; Pedersen 2019). Särskilt viktiga är de prioriteringar som görs i huvudmannens anbud och avtal eftersom de anger specifika förväntningar på det upphandlade sociala arbetet (Almquist \& Högberg 2008). Vidare intar kvalitetssäkring i form av krav på utvärdering av upphandlade insatser en central roll (Lunander \& Andersson 2004) även om sådana krav visat sig vara svåra att specificera och följa upp (Isaksson, Blomqvist \& Winblad 2018).

Syftet med denna artikel är att undersöka hur socialt arbete formas i en upphandlingskontext, med särskilt fokus på hur socialarbetare som arbetar med att utföra upphandlade tjänster beskriver sitt arbete. Mer specifikt vill vi med artikeln besvara följande frågeställningar: Vilka ramar skapar upphandling för det sociala arbetet? Hur formar dessa ramar utförande socialarbetares arbete med klienter? Och hur bidrar dessa ramar till att forma klienten? Vilket socialt arbete blir möjligt inom ramen för upphandlingen och dess marknadsrationalitet?

Artikeln är strukturerad enligt följande: Först presenteras det empiriska sammanhang som undersöks liksom genomförande av materialinsamling och analys. Därefter redogör vi för den teoretiska ansats som vägleder de analyser som görs i artikeln. Sedan presenterar vi huvuddragen i vår analys av det empiriska materialet, $i$ tre olika avsnitt som i tur och ordning uppmärksammar: de ramar som upphandling sätter för socialt arbete genom att skapa en bestämd (och hierarkisk) relation mellan beställare och 
utförare; hur dessa ramar i sin tur inverkar på relationen mellan utförande socialarbetare och klient; samt hur denna relation bidrar till att forma klienten på specifika sätt. Avslutningsvis sammanfattas studiens huvudsakliga slutsatser och diskuteras i relation till några av de utmaningar som socialt arbete står inför i en samtid präglad av upphandling och marknadsorientering.

\section{Analytisk ansats}

I artikeln tar vi avstamp i en forskningstradition som uppmärksammar hur marknadens rationalitet bidrar till att forma det sociala arbetet genom att på olika vis ange ramar för vad som är möjligt att tänka och att göra (Harris 2003; Ferrera 2008; Bay 2019; Katzin 2020) - genom språk, kategoriseringar och mätningar (Holstein 1992). En viktig inspirationskälla är i detta sammanhang Michel Foucault $(1980,1982)$ och hans förståelse av makt och maktutövning (Chambon, Irving \& Epstein 1999).

Analytiskt fokus riktas mot hur makt utövas genom upphandling, i en kontext där sociala tjänster köps och säljs. I linje med Foucaults förståelse så ser vi makt som kontextuell och relationell, det vill säga makt är något som utövas i specifika kontexter, i relationer mellan olika aktörer. I denna artikel riktar vi därför uppmärksamhet mot den maktutövning som utspelar sig och som blir möjlig inom ramen för det upphandlade sociala arbetets kontext, i relationer mellan å ena sidan beställare och utförare av sociala tjänster, å andra sidan mellan utförare och klient. I linje med Foucaults förståelse ser vi därtill maktutövningens dynamik inte enbart som negativ eller reglerande, i den meningen att den begränsar eller kringskär människors handlande. Först och främst ser vi maktutövningens dynamik som produktiv, i den meningen att den på olika vis möjliggör och uppmuntrar till handlanden av bestämda slag. Detta kan gälla både utförande socialarbetare och klienter.

I detta sammanhang knyter vi an till Ken Moffatt (1999:233), som inspirerad av Foucaults tankar noterar att: "The power of the social worker in fact is... 'positive' and technical; the exercise of power creates possibilities for both the worker and the client". Socialarbetarens möjligheter till handling, särskilt i mötet med klienter, brukar förstås i termer av att de som tjänstepersoner verksamma i människobehandlade organisationer har ett visst handlingsutrymme (Skillmark \& Oscarsson 2020). I en kontext som är formad av en marknadsekonomisk rationalitet är det dock, noterar Moffatt, specifika möjligheter för handling som träder fram, för både socialarbetare och klient: "The social worker is an actor in government. The purpose of government in the social assistance office is the creation of the autonomous being" (Moffatt 1999:235). Med avstamp i en sådan förståelse av makt har studier i både Sverige och andra delar av världen visat på hur det inom det sociala arbetet har utvecklats en rad insatser där den enskilda klienten på ett liknande sätt ses som, och på olika vis skapas som, ansvarig för sin egen livssituation, i stort och smått. Sådana insatser kan vara såväl aktiverande som repressiva, inte sällan är de både och (t.ex. Lauri 2016, 2019; Juhila, Raitakari \& Hall 2017; Birk 2018).

Viktigt att poängtera är att vi i denna artikel läser och tolkar de utförande soci- 
alarbetarnas utsagor utifrån en upphandlingskontext, vilket inte behöver utesluta att det skulle vara möjligt att göra andra tolkningar. Mer specifikt riktar vi i artikeln uppmärksamhet mot de relationer som formas mellan de tre huvudaktörer som deltar i upphandlingsprocessen, som alla i någon mening formas enligt en marknadsrationalitet: 1) relationen mellan beställare och utförare, som påvisar de ramar som upphandlingen sätter upp för hur det sociala arbetet förväntas utföras, något som i sin tur påverkar 2) hur relationen mellan utförare och klient formas, kan förstås och ta sig uttryck, vilket slutligen får konsekvenser för 3) hur klienten formas inom ramen för ett upphandlat socialt arbete.

\section{Empiriskt material och genomförande}

Denna artikel baseras på en studie som genomförts i en medelstor svensk kommun som sedan 1990-talet infört och organiserat olika slags marknadsreformer, inte minst i form av kundvals-, beställar- och utförarmodeller, samt genom upphandling av välfärdstjänster. Kommunen kan därmed ses som ett illustrativt fall för en bredare trend vad gäller införande av marknadsliknande reformer inom välfärdsområdet, en trend som pågår runtom i landet, inte minst inom socialt arbete.

I kommunen har närmare bestämt ett system införts med upphandlade tjänster och insatser inom socialtjänsten, inom vilket klienter på egen hand, med eller utan biståndsbeslut, ska kunna välja från ett urval av verksamhets- och företagsprofiler med tjänster och stödinsatser av olika slag. Fallstudien gör det möjligt att empiriskt identifiera nyanser i hur upphandling inom socialtjänstens verksamhet går till i detta enskilda fall. De resultat som presenteras utifrån det empiriska underlaget för denna fallstudie kan därtill ligga till grund för fortsatta studier av andra fall, av upphandling inom socialtjänsten också i andra kommuner runtom i landet, såväl som inom andra välfärdsområden (jfr Flyvbjerg 2006).

Det sociala arbete som särskilt uppmärksammas i denna studie är den del som arbetar med utförandet av det upphandlade sociala arbetet. En del av socialtjänstens arbete organiseras i en beställarfunktion, där kommunala nämnder ansvarar för de övergripande upphandlingar som ska genomföras och följas upp. En annan del av arbetet delas upp i två funktioner: det utredande och det utförande sociala arbetet. Dessa funktioner är sedan specialiserade mot olika, på förhand, avgränsade målgrupper av det social arbetets behovsområden, till exempel familjestöd, beroendestöd, barn, ungdomar, äldre och socialpsykiatri. Socialarbetare som sköter den utredande funktionen ska utreda behov och besluta om insatser som sedan skickas till den utförande funktionen som en beställning eller ett avrop alternativt genom direktupphandlingar. Den utredande funktionen beställer enligt upphandlingens logik tjänster i enlighet med det ramverk som finns för upphandlade utförare, vilka ansvarar för att genomföra det upphandlade sociala arbetet. Utförarna ska arbeta utifrån de mål och medel som avtalen anger, under den begränsade tid som beställningen gäller. I denna studie riktas intresset mot hur dessa utförande socialarbetare beskriver sitt arbete i ett sammanhang omgärdat av avtalsformuleringar, beställningar från utredande socialsekreterare samt klientens önskemål och behov. 
Tanken är att de klienter som utförarna kommer i kontakt med antingen själva ska kunna söka sig till utförarnas verksamhet, eller ha hänvisats dit genom en beställning från en utredande socialsekreterare som fattat ett biståndsbeslut. De insatser som utföraren erbjuder är dock desamma, oavsett om klienten själv sökt sig till verksamheten eller fått ett beslut från en utredande socialsekreterare. Insatserna och hur arbetet ska utformas är nämligen tänkta att styras av upphandlingsavtalen.

Urvalet av intervjuer har gjorts brett, för att kunna rikta uppmärksamhet mot utförande socialarbetare inom olika verksamhetsområden (med sina respektive målgrupper) och inom olika verksamhetsformer (privat och kommunal regi). Centralt för ett sådant upplägg är att socialarbetarna i de olika verksamheterna är förenade i ett organisatoriskt sammanhang där det gemensamma är upphandlingsstrukturen. Utförarna har det gemensamt att de är upphandlade av kommunen för att utföra tjänster och insatser enligt särskilda avtalsformuleringar. Ett sådant upplägg, med utförare inom olika verksamhetsområden och verksamhetsformer, har också valts för att kunna identifiera och fånga upp det som återkommer i socialarbetarnas tal om sitt arbete som utförare.

Det empiriska underlaget består av intervjuer med sammanlagt 16 utförare av upphandlat social arbete. Intervjupersonerna kontaktades med information om studien, dess syfte och hur intervjuerna kommer att hanteras för att möjliggöra en avidentifiering. Samtycke om medverkan i studien har inhämtats från intervjupersonerna, med en överenskommelse om att intervjumaterialet så långt som möjligt ska anonymiseras.

De socialarbetare som intervjuats arbetar med att erbjuda tjänster och insatser inom fyra olika verksamhetsområden: familjestöd, missbruksstöd, socialpsykiatri samt en stöd- och vägledningsenhet. Detta urval av verksamhetsområden och verksamhetsformer är alltså verksamheter som är upphandlade av kommunen. Dessa verksamheter utgörs av två enheter för familjestöd (en privat och en kommunal utförare), två enheter för socialpsykiatri (en privat och en kommunal utförare), en kommunal enhet för beroendestöd samt en kommunal enhet för stöd och vägledning. Intervjuerna genomfördes under 2014-2015 och varade mellan 45 och 75 minuter. Intervjuerna var semistrukturerade och kretsade kring socialarbetares syn på hur det är att arbeta i verksamheter som erbjuder upphandlade sociala tjänster, med särskilt fokus på organisering, handlingsutrymme och relationen till klienterna. Intervjuerna har transkriberats ordagrant och utgörs sammantaget av 218 sidor intervjutranskriptioner. Intervjumaterialet har anonymiserats. Vid citat anges en bokstav, en siffra och information om vilken inriktning utföraren är verksam inom. Bokstaven representerar den enhet som intervjupersonen arbetar inom och siffran särskiljer intervjupersonen från andra som arbetar inom samma enhet.

Med utgångspunkt i vår analytiska ansats har vi närmat oss dessa intervjutranskriptioner som utsagor. Utsagorna ska tolkas som ett skapande av mening om verkligheten som formuleras i mötet mellan forskare och intervjuperson. Intervjumaterialet kan därmed ses som ett slags gemensamt skapande av mening om världen (jfr Wetherell 2004). Uppmärksamhet har riktats mot hur socialarbetarna talar om att arbeta som upphandlad utförare av socialt arbete på en marknad av tjänster och insatser. Samtliga 
intervjutranskriptioner har lästs var för sig och tolkats som utsagor som tagit form i en specifik kontext, vid en given tid. Bearbetningen har därmed tagit fasta på att utförarna arbetar inom olika inriktningar av det sociala arbetet, men att samtliga utförare samtidigt har erfarenhet av att bedriva socialt arbete inom ramen för en upphandlad verksamhet. Utifrån en sådan utgångspunkt har fokus riktats mot socialarbetarnas utsagor om det upphandlade sociala arbetet. Med avstamp i den analytiska ansats som vi redogjort för ovan tolkas utsagorna mer specifikt med hänsyn till hur makt utövas genom upphandling, i termer av de krav, förväntningar och de ramar för arbetet som skapas i enlighet med det uppdrag som har avtalats och den insats som beställts samt behov och önskemål från klienter. Vi har här närmat oss dessa utsagor genom att rikta uppmärksamhet mot hur dessa förutsättningar eller ramar för arbetet benämns - i form av de värden, ansvar, möjligheter och begränsningar som dessa tillskrivs - samt vilka relationer dessa ramar möjliggör. Vi har också särskilt uppmärksammat hur makt utövas och produceras i specifika kontexter och relationer mellan de aktörer som påverkar utförandet av det sociala arbete som beställs. Det handlar här om relationerna beställare-utförare och utförare-klient, men fokus riktas även mot hur klienten formas inom ramen för det upphandlade sociala arbetet. Presentationen av vårt material och vår analys kommer följa denna struktur. Först fokuserar vi på hur upphandlingen sätter ramar för det sociala arbete som är överenskommet att utföras med särskilt fokus på beställare och utförare. Därefter rör vi oss vidare ner mot relationen mellan utförare och klient, innan vi avslutar med att analysera hur klienten formas genom upphandlingen.

\section{Upphandlingens avgränsningar i tid och antal}

I upphandlingen mellan beställaren, som i det här fallet är kommunen, och utföraren beskrivs och bestäms det innehåll och de villkor som är tänkta att styra det sociala arbete som ska erbjudas. Avtalen som skrivs är och ska vara tydligt specificerade och strukturerade. Upphandlingen sätter därigenom ramar för det konkreta, praktiska sociala arbetet, och för personalen som arbetar som utförare blir avtalen något som de behöver förhålla sig till i sitt dagliga arbete. I det här avsnittet kommer vi särskilt lyfta fram hur upphandlingen sätter ramar för det sociala arbetet och hur detta skapar relationer mellan beställare och utförare. Ett exempel är hur uppdraget ofta beskrivs som en beställning:

Vi har ju i vårt uppdrag, eller $i$ vår beställning så då, från omsorgsnämnden, så sägs det att vi ska kunna erbjuda tid inom fjorton dagar. För det mesta kan vi göra det, den första besökstiden. (A1, socialarbetare inom stödsamtal och vägledning)

I det här fallet styr avtalet när och hur den första besökstiden ska genomföras. Omsorgsnämndens upphandling av denna specifika utförarverksamhet och dess tjänster, beskrivs här som ett beställningsjobb, ett uppdrag som formar särskilda tidsramar. Den utförande socialarbetarens uppdrag blir därefter att följa beställningen och genomföra 
första besökstiden inom ramen för det avtal som tecknats mellan utförare och beställare. Eftersom upphandlingsavtal ska anses vara tydliga och specificerade nog, krävs ofta att det sociala arbetet i någon form kvantifieras (Upphandlingsmyndigheten och Konkurrensverket 2020). Tidsfaktorn är en sådan kvantifiering som ofta används. Vi kommer därför återkomma till tiden som ett viktigt medel för hur det sociala arbetet styrs.

Bland utförarna, socialarbetarna, tolkas upphandlingen framförallt som ett ramverk som delvis avgör vilket socialt arbete som är möjligt eller tillåtet att genomföra. Ett ramverk som även innebär viss administration och som inte alltid kan fånga de behov som finns hos klienterna.

Så får man ju beställningspapper, det står lite bakgrund och hur det har varit, lite grann hur behovet är, hur mycket tid som behövs och så då. [...]. Och den kan ju vara föränderlig den kan ju, ändras med tiden också [...]. Antal timmar för insatsen, om det ska ändras eller så, då är, eftersom [namn på företag] får ersättning för just den tiden då är det ju naturligtvis viktigt att vi tar kontakt med soc. (E1, socialarbetare med inriktning mot socialpsykiatri)

E1 beskriver hur den konkreta beställningen går till i samband med att en ny klient blir aktuell. Utföraren får ett beställningspapper med information om klienten och dennes behov, men också om hur mycket tid som beställts för det enskilda ärendet. Ännu en gång blir tiden avgörande. Om det under arbetets gång visar sig att klientens situation kräver mer tid, måste utföraren kontakta beställaren igen så att denna kan göra en ny beställning. Om utföraren skulle fortsätta arbetet utan att en ny beställning har gjorts, stämmer inte längre den ersättning utföraren får för klienten.

Så att vi har en ram som går ut på att de våra chefer har träffat, beställarna och liksom fått uppdraget och klargjort för sig och sagt, lite grann, förutsättningarna för oss: "Just nu har vi kanske inte så många boendestödjare som kan gå in så mycket" eller något sådant där. (E2, socialarbetare med inriktning mot socialpsykiatri)

Som nämnts ovan beskriver socialarbetarna upphandlingen som ett ramverk som delvis avgör vilket arbete som är möjligt att utföra. I denna process tycks dock den utförande socialarbetaren själv få en relativt passiv roll. Det är chefer som skriver avtalen med beställarna och socialarbetaren blir den som ska omsätta beställningarna av uppdragen till handling. De utförande socialarbetarna beskriver sig därigenom själva som passiva aktörer, som tvingas foga sig efter den ram andra aktörer ställt upp i avtalen.

Upphandlingarnas beställning av ett socialt arbete och socialarbetarnas roll som passiva aktörer i relation till avtalens villkor påverkar i allra högsta grad det sociala arbetet. B2 som arbetar med familjestöd menar att de villkor som anges i avtalen inneburit färre möjligheter att erbjuda vissa former av socialt arbete, exempelvis ett mer förebyggande och områdesbaserat arbete. I stället tvingas den utförande socialarbetaren att hålla sig "inom ramen för avtalen nu": 
Jag tänker att eftersom vi nu är upphandlade som både kommunala och privata verksamheter så blir det ju också, ja, hur ska jag säga? [...] Vi behöver ju ändå hålla oss inom ramen för avtalen nu. Och det är klart att förebyggande arbete på det gamla sättet - att finnas i ett område och se - det, åtminstone för mig som socialarbetare här, så försvinner det lite. (B2, socialarbetare inom familjestöd)

B2 visar härigenom hur det kan finnas en hierarki för vilket socialt arbete som beställs och inte. Citatet kan också tolkas som ett tecken på att avtalen och avtalsförfarandet gynnar vissa former av socialt arbete framför andra. Som vi nämnde inledningsvis kräver avtalen en tydlighet, en specificering och en struktur som kan vara svårare att applicera på vissa former av socialt arbete, exempelvis det förebyggande och områdesbaserade. Antalet möten som beställs och den tid som avsätts för respektive klient i avtalen är exempel på hur ett individanpassat och behandlingsfokuserat socialt arbete kan gynnas framför andra former av arbete.

Upphandlingen påverkar hur de utförande socialarbetarna ser på sitt arbete, vilka möjligheter de har för att utföra sitt arbete och i förlängningen vilket socialt arbete som kan erbjudas. Det sistnämnda, vilket socialt arbete som tillgängliggörs, innebär också att relationen mellan utförande socialarbetare och klient kan påverkas av upphandlingsförfarandet. Detta kommer vi in på i nästa avsnitt.

\section{Upphandlingens kvantifiering av arbetet}

Upphandlingen som sker mellan beställare och utförare påverkar också det arbete som socialarbetare (utföraren) utför i relation till klienterna. Avtalen som skrivs innehåller en specificering av arbetet och själva uppdraget. En sådan specificering kan, som vi sett exempel på, handla om att kvantifiera antalet träffar som ska ingå, vilka klienter som avtalet gäller och vilka typer av insatser som får lov att erbjudas. Därigenom får avtalen också konsekvenser för den utförande socialarbetarens arbetssituation och för det konkreta möte som sedan sker med klienterna.

Konsekvenserna för arbetet och mötet med klienten blir särskilt tydligt i kvantifieringen av arbetet som specificeras i upphandlingen. C1 som arbetar med familjestöd berättar hur de måste mäta timmarna som går åt till respektive familj.

Vi måste ju mäta timmarna. Varje månad måste vi se hur många timmar vi har jobbat med precis den här familjen. Och redovisa det. Vi får liksom inte betalt om vi inte gör någonting. Så det måste vi mäta. Vi måste ha koll liksom. Om vi har 3100 timmar så kan vi ju inte jobba 5000 och få betalt. Alltså, jobbar vi mer, och det har vi gjort flera år, gått över. Då har vi ju fått stå för det. Själva. Så det är ju vårt ansvar att se till att det fungerar. (C1, socialarbetare inom familjestöd)

Upphandlingen kvantifierar arbetet, vilket leder till att utförande socialarbetare har ett visst antal timmar till förfogande för respektive familj och till att socialarbetaren därför behöver kunna redogöra för hur det konkreta arbetet utförts i antalet timmar. 
Det sätter ramar för vilket socialt arbete som är möjligt att genomföra. Dessa ramar överensstämmer inte alltid med familjens behov eller socialarbetarens egen bedömning av vad som krävs för den enskilda familjen. C1 berättar hur detta får konsekvensen att personalen behöver arbeta mer tid än den tilldelats. För att hantera upphandlingens konsekvenser för det sociala arbetet tvingas socialarbetarna alltså kompensera för den brist på tid som avtalen i praktiken innebär. Denna kvantifiering av arbetet och den tidsbrist som därigenom kan uppstå, får dock inte enbart konsekvenser för socialarbetarens tid. Det får också konsekvenser för klientens tid. A2, som arbetar med stödsamtal och vägledning, ger ett exempel på hur en klient tilldelas ett visst antal besök i enlighet med den upphandling som gjorts:

Då kan man ju säga det, innan sista samtalet, att: "Nästa gång kanske vi måste fundera ihop, är du nöjd med det här eller behöver du någon annan hjälp eller något annat stöd nu?’ Så då får man ju använda den sista gången till att försöka fundera tillsammans: "Vad kan vara möjligt här?" Och det är inte alltid så lätt. (A2, socialarbetare inom stödsamtal och vägledning)

A2 berättar hur det sista stödsamtalet, som en effekt av att det finns en begränsning i antalet samtal, måste användas till att tillsammans med klienten lista ut vart denne ska vända sig om det finns fortsatt behov av hjälp och stöd. Här syns tydligt de begränsningar som upphandlingen medför och hur dessa både påverkar arbetssituationen och mötet med klienten. Upphandlingen formar mötet med klienten och tar de facto tid från den redan begränsade mötestiden. Eftersom uppdraget är begränsat i tid eller antalet träffar måste utföraren anpassa situationen efter upphandlingen snarare än efter de sociala behov klienten har. I det ovanstående exemplet innebär detta för den utförande socialarbetaren att stödet omvandlas till en situation som går ut på att lista ut vart klienten kan vända sig framöver, "och det är inte alltid så lätt".

Både $\mathrm{C} 1$ och $\mathrm{A} 2$ ger exempel på hur utförande socialarbetare själva kan behöva kompensera för eller hitta strategier för att hantera systemets brister. Kompenseringen sker i det här fallet antingen genom att socialarbetaren tar sig tid utöver den tid som räknas eller genom att socialarbetaren tar av den begränsade tid som finns, för att försöka hitta andra former av hjälp som kan finnas tillgängliga för klienten. Upphandlingen medför emellertid inte endast en kvantifiering av arbetet genom att gränser för tid och antalet möten sätts; den formar även arbetet genom att på förhand avgöra målgruppen för arbetet. Målgrupper som de socialarbetare som ska utföra arbetet behöver kunna förhålla sig till i sitt arbete och i mötet med klienten. Detta blir särskilt tydligt när avtalen förändras.

Förut hade vi samtalsavtal plus gruppavtal. Men nu har vi... det här familje... Vi har alltid jobbat familjeinriktat, men nu är det liksom bara en konstruktionsfråga. Det är ett annat avtal vi har nu. [...] Vi har ju fått en vidare målgrupp nu sedan 2011. [...] Men vi jobbar. Alltså vår grund, hur vi jobbar, det är ju likadant. (C1, socialarbetare inom familjestöd) 
C1 förklarar här hur de på arbetsplatsen har haft ett antal olika avtal med kommunen som alla innehåller olika målgrupper. Som C1 beskriver det så har arbetsplatsen sedan 2011 ett avtal som avser en "vidare målgrupp" än tidigare. Avtalen sätter därigenom gränser för vilka klienter som det är tänkt att utförarna ska arbeta med. Men även om avtalen sätter sådana gränser, visar C1 samtidigt på hur utförarna själva står på en "grund" som de, oavsett upphandlingens formuleringar, fortsätter att arbeta utifrån. Detta tyder på att det finns ett visst utrymme för förhandlingar och motstånd i det dagliga arbetet, trots upphandlingens relativt statiska skrivningar.

I det här avsnittet har vi sett exempel på hur upphandlingen skapar förutsättningar för vilket socialt arbete som är möjligt, med fokus på hur arbetet med klienter förväntas utföras. Bland annat bestämmer avtalen vilka målgrupper som ska omfattas av arbetet, hur ofta utförande socialarbetare ska träffa klienter och hur lång tid insatserna får fortgå. Det bidrar till en kvantifiering av arbetet och en kortsiktighet som utförande socialarbetare själva många gånger behöver kompensera för. Samtidigt finns det exempel på hur socialarbetare också ägnar sig åt förhandlingar och gör motstånd, såsom att arbeta i enlighet med en vidare "grund" oavsett vad upphandlingen säger. Trots detta motstånd och de förhandlingar som sker skapar upphandlingsförfarandet ett starkt fokus på de områden av det sociala arbetet som är möjliga att mäta. Ett fokus som kan tolkas som en anpassning till en marknadsekonomisk rationalitet (Holstein 1992), där det mätbara och avgränsningsbara gynnas på bekostnad av klienternas sociala behov av stöd och hjälp. På så sätt sätter upphandlingen tydliga ramar för det arbete som utförs. Därutöver sätter det även ramar för hur klienten skapas och då inte enbart som tillhörande en bestämd målgrupp utan även hur den enskilda klienten själv skapas på särskilda sätt. Detta kommer vi diskutera i nästa avsnitt.

\section{Klienten som beställning och ärende}

Upphandling skapar inte bara relationer mellan beställare och utförare eller mellan utförare och klient. I förlängningen bidrar upphandlingen dessutom till att klienten formas på bestämda sätt, enligt de ramar som styr upphandlingen. Som ett resultat träder klienten fram som ett objekt, i olika skepnader: som potentiell ekonomisk tillgång, beställning och ärende.

Hur klienten formas som objekt synliggörs inte minst om vi närmare undersöker vad som sker när klienten anländer till en utförare efter att en beställning gjorts. Låt oss inleda med ett exempel där C1 berättar vad som händer när en klient anländer till den privata verksamhet med inriktning mot familjestöd där hon är verksam. Först gör utföraren en samlad bedömning av klientens behov och önskemål. Denna bedömning bygger på inhämtande av olika slags kunskap om klienten, som i sin tur kan ligga till grund för det fortsatta arbetet. I denna verksamhet inhämtas sådan kunskap genom att klienten ombeds fylla i ett självskattningsformulär: 
Kommer de hit så får de fylla i en utvärdering. Vi har ju ett formulär som man fyller... när man kommer och när man går. Och i det skattar man varför kommer du hit och vad är ditt problem och vad förväntar du dig och så får man skatta olika symtom med tillit och mat och sömn och sådana grejer. Och så lite grann en koll också om hopp och framtidstro. Vi har sådana frågor. [...] Jag kan ju säga hur mycket som helst, de skulle kunna göra det och det och det och det... Men jag försöker ju att hålla mig tillbaka. Så att jag säger så här: "Kom hit och så gör vi en plan och så jobbar vi efter det. För att vi har så här..." Jag får ju ibland passa mig för att inte bara slänga fram allting på en gång, för då kan man ju... För jag har ju skrämt iväg en och annan på det... Genom mitt liv. (C1, socialarbetare inom familjestöd)

Av citatet framgår att utföraren medvetet träder tillbaka för att på så vis ge initiativet till klienten, som görs delaktig i att ta fram ett underlag för en bedömning av klientens behov och önskemål. Denna inventering används därefter för att ta fram en plan för det fortsatta arbetet med klienten. $\mathrm{C} 1$ understryker samtidigt att det ibland kan vara svårt att hålla tillbaka och inte ta över initiativet i detta initiala skede. Utifrån sina tidigare erfarenheter noterar hon att det alltid finns en risk att som utförare skrämma iväg klienten om utföraren tar över initiativet alltför mycket. Detta kan tolkas som en välvilja att inte skrämma iväg en klient i behov av stöd, men om vi läser citatet i relation till att klienten i just detta fall har anlänt till utföraren efter det att en beställning är gjord, är det även möjligt att tolka utsagan i termer av en ekonomisk rationalitet. Även om det inte sägs uttryckligen, utgör varje klient också en potentiell resurs för utföraren, en ekonomisk tillgång som det gäller att vårda och inte riskera.

Huruvida klienten är en ekonomisk tillgång eller inte grundar sig i sin tur på en bedömning av klientens behov och hur väl de kan matcha de tjänster som utföraren erbjuder. På en fråga om det förekommer beställningar där klienter anländer med behov som inte bedöms matcha de tjänster som erbjuds säger B1, som arbetar i en kommunal verksamhet som erbjuder familjestöd, följande:

När vi tycker att: "Det här kanske inte är någonting för oss", då får ju vi backa tillbaks till socialkontoret. Alltså, om de har skickat en beställning till oss så kan det ju bli en diskussion däremellan: "Vad är bäst egentligen, i det här läget? Skulle det inte vara bättre med det här?” Det kan ju vi få lite kritik för, att vi ifrågasätter. Så kan det vara. Men...Tanken är väl att det ska vara en öppen dialog emellan. (B1, socialarbetare inom familjestöd)

I beskrivningen träder klienten fram som en beställning, som just i detta fall inte bedöms matcha det utbud av tjänster som utföraren erbjuder. Vad som sker vid sådana tillfällen är inte givet på förhand. Utifrån den bedömning som utföraren gör blir nämligen klienten i dessa fall föremål för en förhandling och blir på så vis till ett slags objekt för andras blickar och bedömningar, om var någonstans beställningen bör hamna. Som B1 beskriver det är ambitionen vid sådana tillfällen att det ska föras en "öppen 
dialog”, som involverar såväl beställare som utförare. Till skillnad från i föregående exempel är det dock i detta fall inte klienten som ges initiativet i den dialog som förs (och den bedömning som dialogen till slut är tänkt att mynna ut i). Klienten tar här snarare formen av ett föremål - för dialog eller förflyttning mellan olika utförare - utan nämnvärd möjlighet till egen agens.

Båda föregående exempel illustrerar hur klienten skapas som objekt (i form av ekonomisk tillgång och beställning) i samband med att en beställning är gjord och klienten anländer till en utförare. Låt oss nu rikta uppmärksamhet mot ett senare led i processen, där beställningen fullföljts och arbetet utförts, och hur klienten skapas som objekt på ett annat vis, nämligen som ärende. På frågan om det sker någon typ av uppföljning efter det att en klient har tagit del av de tjänster som erbjuds, beskriver A1 arbetsgången i den kommunala verksamhet som erbjuder stödsamtal och vägledning på följande vis:

Avslutar vi här så följer vi inte upp det efteråt. Det gör vi inte [...] vi lämnar över ett ärende. Men sedan släpper vi ju det. De rapporterar inte tillbaka till oss, hur det har gått eller något sådant. [...] Personligen så tycker jag att det är ett bra sätt. Man påbörjar, man jobbar och sedan avslutar man och sedan släpper jag det och sedan kommer jag inte ihåg det. Jo, det gör jag, om det är någon som hör av sig igen så brukar jag komma ihåg. Men alltså, det fungerar bra för mig alltså, att det är ett avslut och sedan släpper jag det. Jag har inte så stort problem med det. Det är klart jag kan undra: "Hur gick det för den?" Men inte så att jag måste veta. Jag kan släppa taget. (A1, socialarbetare inom stödsamtal och vägledning)

I citatet beskrivs det arbete som utförs i relation till klienten som en hantering av ett ärende. När det är tid att avsluta ett ärende, efter det att uppdraget enligt avtal är slutfört, tycks i detta fall ingen uppföljning göras. Av vad som framkommer i citatet tycks inte heller klienten rapportera tillbaka efter det att uppdraget är slutfört. Resonemanget illustrerar på ett tydligt vis hur klienten formas enligt den kortsiktighet som upphandlingen skapar. På grund av den begränsade tid som upphandlingen ger utrymme för etableras ingen långvarig relation mellan utförare och klient. Relationen är i stället av mer kortsiktig och instrumentell karaktär, där utföraren inte säger sig ha några svårigheter med att släppa ärendet och gå vidare.

I det här avsnittet har vi sett hur klienten på olika vis formas utifrån de ramar som upphandlingen skapar, och de relationer mellan beställare och utförare samt mellan utförare och klienter som dessa ramar i sin tur möjliggör. Klienten beskrivs genom den ram som upphandlingen skapar för det sociala arbetet. Det är en ekonomisk rationalitet som bidrar till att klientens sociala behov samsas med de ekonomiska förutsättningarna i relation till de avtal som skrivs. Klienten blir här en tillgång för utförarna, där det kan handla om att försöka behålla klienter för att inte förlora ekonomisk ersättning eller i förlängningen potentiellt också förlora ett avtal. Upphandlingslogiken, med sin mätbarhet och kortsiktighet, bidrar även till att skapa förutsättningar för att klienten kan tolkas i termer av ett objekt som byter händer. Detta syns dels i beställningsför- 
farandet där klienter som inte anses matcha sänds åter för att en ny beställning till samma eller annan utförare ska genomföras, dels i hur klienten kan omvandlas till ett ärende som avslutas när beställningen upphör och klienten kan skickas tillbaka till beställaren. Klienten riskerar genom upphandlingens logik att omvandlas till ett ärende, som utförs, avslutas och som glöms bort.

\section{Avslutande reflektioner}

I denna artikel har vi fokuserat på det sociala arbete som blir till i en kontext av upphandling. Inom ramen för en bredare marknadsekonomisk orientering uppmuntras kommuner runtom i landet till upphandling av allehanda tjänster och insatser. Så sker även inom det sociala arbetets olika verksamhetsområden. I den här artikeln har vi riktat uppmärksamhet mot hur socialarbetare som arbetar med att utföra sådana upphandlade tjänster beskriver sitt arbete. Genom att närmare undersöka hur utförande socialarbetare beskriver sitt arbete kan vi samtidigt få syn på vad upphandling gör med det sociala arbetet och vilket socialt arbete som blir möjligt inom ramen för upphandlingen och dess marknadsrationalitet. Mer specifikt har vi riktat fokus mot de ramar upphandlingarna skapar för det sociala arbetet, socialarbetarens arbetssituation med klienter och hur klienten i förlängningen beskrivs och förstås. I denna avslutning vill vi mot bakgrund av de ramar som skapas av en marknadsorientering diskutera vad det är för slags socialt arbete som möjliggörs av en sådan rationalitet. Eller för att uttrycka det annorlunda, vilket socialt arbete träder fram när socialarbetare beskriver det arbete de utför i en upphandlingskontext?

Upphandlingen följer en särskild logik: den ska innehålla begripliga, avgränsade uppdrag och gälla specifika målgrupper av människor, med sina specifika behov och problem. Det kan handla om samtals-, familje- eller gruppavtal, som en av de socialarbetare som intervjuats talar om. Avtalen innebär därför att utförarna behöver skapa avgränsade varor som passar kommunens krav inom ramen för de avtal som tecknats och klienten blir härigenom en ekonomisk resurs för utföraren.

Detta förfarande tycks i sin tur leda till utvecklande av särskilt specialiserade insatser, där innehållet snabbt kan komma att förändras mellan olika avtalsperioder. De förändringar som socialarbetarna beskriver tycks framför allt ske på basis av kommunens beställning snarare än på utförande socialarbetares kompetens eller klientens behov. Klienterna omvandlas därigenom från människor med behov till varor som kan matchas mot särskilda målgruppsinriktade erbjudanden om stöd och insatser, avgränsade till upphandlingens avtalade utbud. De riskerar att flyttas mellan olika insatser på grund av att de inte matchas med den tjänst som beställts av kommunen och den insats som utförande socialarbetare har att leverera, enligt avtalet. Klienter som genomgått den insats som beställts flyttas tillbaka till beställaren.

Kvantifiering av tid och antalet träffar är en väsentlig dimension av upphandlingen, vilket ligger i linje med ökade mätbarhetskrav i socialt arbete (Martinell Barfoed 2014; Chandler, Bell, Berg m.fl. 2015; Hjärpe 2020). Det sociala arbete som beskrivs av de socialarbetare som intervjuats får i alla steg en inbyggd kortsiktighet. Kommunen be- 
ställer tjänster under en specifik tidsperiod som utförande socialarbetare under denna period förväntas utföra och leverera. Innehållet kan skilja sig åt mellan avtalen, vilket också skapar en svårhanterad situation för de socialarbetare som på kort tid förväntas ställa om och anpassa sig till de nya krav som ställs vid upphandlingen. För klienternas del begränsas ofta insatserna i tid, vilket inte minst innebär att de kan behöva nya insatser i takt med att tidigare insatser avslutas. Vidare innebär kortsiktigheten att socialarbetarens arbetssituation påverkas då beställningen kan ställa krav på att tiden som läggs på respektive klient regelbundet mäts och följs upp. Eftersom uppdraget får detta kvantifierade och styrda upplägg har vi sett exempel på hur klientarbetet anpassas efter upphandlingen i stället för att anpassas efter klientens sociala behov. Detta blir inte minst tydligt när utförande socialarbetare bedömer att klienten har behov av ytterligare stöd och hjälp som inte omfattas av avtalet. Här har vi sett exempel på hur utförande socialarbetare kompenserar för den brist på tid och tillfällen som avtalet i praktiken innebär genom att antingen ta av sin egen tid eller att ta av klientens tid för behandling, stöd och hjälp för att kunna få tid att hitta alternativ för fortsatt stöd.

De utförande socialarbetarna beskriver både sig själva och klienterna som passiva i relation till upphandlingens logik. Uppdraget beskrivs som en beställning eller som en ram som den utförande socialarbetaren måste anpassa sitt arbete efter och klienten beskrivs som en passiv mottagare som kan förflyttas mellan utförare och beställare, samt mellan olika utförare. Samtidigt visar socialarbetarna genom hur de agerar att de har ett visst handlingsutrymme där de, som ovan nämnts, både går utöver den beställda tidsåtgången för att stötta och hjälpa klienter och anpassar antalet besök för att hitta en strategi för att anpassa den statiska beställningen efter klientens liv och sociala villkor. Detta handlingsutrymme tycks dock antingen drabba socialarbetarna själva eller klientens möjligheter till hjälp och stöd.

Eftersom det är en viss typ av kortsiktigt, specialiserat och avgränsat socialt arbete som möjliggörs genom upphandlingarna, så innebär denna logik att andra former av socialt arbete träder i skymundan. Det skapas en hierarki av olika former av socialt arbete. Inte minst drabbas det sociala arbete som kräver mer långsiktighet (se också Dahlstedt \& Lalander 2018). Ett exempel på detta är det relationsskapande arbetet som en stor del av det sociala arbetet bygger på och som ofta lyfts fram som en viktig del av det sociala arbetet, eller rentav som en förutsättning för att sociala insatser ska kunna bidra till social förändring (se Bečević 2015; Lindahl 2019). Att relationen riskerar att träda i bakgrunden syns inte minst genom hur klienter förflyttas mellan utförare eller mellan beställare och utförare, och att detta inte alltid tycks ske mot bakgrund av klientens sociala behov utan som en effekt av en marknadsorientering och upphandlingens ramar. Men också här är det möjligt att tolka socialarbetarnas strategier som ett potentiellt motstånd där de utför ett relationellt arbete med klienter genom att gå utöver de gränser som avtalen anger. De utförande socialarbetarna behöver därmed på egen hand kompensera för de delar av arbetet som inte ingår i upphandlingarna, då de där varken värderas eller uppmärksammas. Marknadsorienteringen i socialt arbete tycks skapa ett behov av kompensation av upphandlingens brister snarare än en kompensation för effekterna av social ojämlikhet (Härnbro 
2021). Ett annat exempel på ett socialt arbete som träder i skymundan, och som uttryckligen nämns av en av socialarbetarna, är det förebyggande områdesbaserade sociala arbetet. Ett arbete som är svårare att mäta och följa upp. Detta tyder på att upphandlingen skapar tydliga ramar för en viss sorts socialt arbete och att de samtidigt bidrar till att annat socialt arbete riskerar att utgå helt. Detta är allvarligt, särskilt då det sociala arbetet har ett tydligt uppdrag att arbeta förebyggande och då vi vet att detta arbete i allt mindre utsträckning sker (Utredningen Framtidens socialtjänst 2020).

Makt utövas som nämnts i specifika kontexter och i relationer mellan olika aktörer (Foucault 1980, 1982). I de relationer och kontexter vi särskilt uppmärksammat i denna artikel är det möjligt att peka på ett antal exempel på hur maktutövning och styrning tar sig form som en följd av det upphandlade sociala arbetet. Även om det kan finnas ett utrymme för alternativa tolkningar av de utförande socialarbetarnas utsagor, menar vi att även de allmänna utmaningar som kan identifieras inom dagens sociala arbete kan bli än mer påtagliga i upphandlingens kontext. Ett sådant exempel är hur kategoriseringar av målgrupper, som naturligtvis förekommer inom socialt arbete oavsett om verksamheten upphandlas eller inte, blir än mer påtagliga genom upphandlingen. Upphandlingen ställer nämligen krav på specialisering av målgrupper och insatser samt på skarpa avgränsningar av vad som ingår i uppdraget och inte, vilket därigenom utgör exempel på hur det sociala arbetet styrs. Kategorisering av målgruppen blir ett viktigt led i denna styrning. Den hierarki mellan olika former av socialt arbete, där visst utövande gynnas på bekostnad av annat, är också ett exempel på hur det skapas ramar för det sociala arbetet. Socialarbetarnas beskrivning av hur både klienter och utförande socialarbetare i viss mån tolkas som passiva aktörer $\mathrm{i}$ relation till upphandlingens och beställningens krav och riktlinjer är ytterligare ett exempel som i någon form tycks beskriva en känsla av maktlöshet där beslut fattas av någon annan, någon annanstans. Upphandlingens makt är emellertid, som vi också varit inne på, inte enbart reglerande utan även produktiv, vilket blir synligt genom socialarbetarnas handlingsutrymme där de kan gå bortom avtalen och exempelvis ge mer tid än avtalat. Som Moffatt (1999) är inne på, tycks detta dock handla om ett handlingsutrymme som möjliggörs inom ramen för en specifik marknadsekonomisk kontext, varför den tid som socialarbetarna tar av för att finna vägar bortom avtalen alltid tycks tas av deras egen eller av klienternas.

Sammanfattningsvis kan vi konstatera att upphandlingskontexten skapar ramar för vilket socialt arbete som blir möjligt. Upphandlingsförfarandet bidrar till en avgränsning, specialisering och till en kortsiktighet av arbetet. Vidare premieras de delar av socialt arbete som lättare kan omvandlas till mätbara, kortsiktiga och specialiserade insatser, på bekostnad av andra, mer relationsbaserade, långsiktiga och förebyggande insatser. Dessa iakttagelser kan ha bäring också för andra delar av välfärdsstaten, inte minst för utbildningssektorn och de marknadsreformer som införts inom både grundskola, gymnasium och vuxenutbildning, samt även vård och omsorg genom införandet av olika slags kundvalssystem, eller för den delen andra organisationer inom välfärden. Även om olika delar av välfärdsstaten har arbetat med olika sätt att implementera en 
marknadsreform, exempelvis genom olika val eller upphandling, finns vissa gemensamma nämnare som gör det troligt att det förekommer viss överlappning. Denna överlappning kan handla om hur en marknadsrationalitet förväntas leda till en ökad effektivitet och därmed också goda resultat, och att detta förväntas ske genom ökad mätbarhet, tidsstyrning, specialisering samt tydliga avgränsningar av behov och insatser (jfr Dahlstedt \& Fejes 2019; Katzin 2020; Holmqvist, Fejes \& Nylander 2021).

Upphandling som en del av en bredare marknadsorientering har inte uppmärksammats i särskilt stor omfattning inom socialt arbete. I detta sammanhang kan de resultat som vi har presenterat i denna artikel bidra till att rikta uppmärksamhet mot upphandlingens betydelse för hur det sociala arbetet i praktiken kan och får utföras. Därtill pekar de resultat som vi presenterat på behovet av ytterligare forskning som kan skapa mer fördjupad kunskap om upphandlingens utbredning och omfattning, hur upphandlingen sätts i bruk samt vilka konsekvenser den har inom det sociala arbetets utförandeled.

Slutsatserna som vi har presenterat kan i viss mån knyta an till studier som tidigare har pekat på hur en tilltagande marknadsorientering av socialt arbete på olika sätt bidrar till att göra klienter ansvariga för sin egen sociala situation (Scourfield 2007; Harris 2014; Vitus 2017). Vi ser dock exempel på hur inte endast klienten formas och görs ansvarig, utan att detta även gäller de enskilda utförande socialarbetarna. Socialarbetarna görs både ansvariga för att utföra och administrera det som avtalen kräver - såsom att matcha tid efter behov, genomföra mätningar och dra gränser som satts upp av avtalet - och för att tillgodose klientens behov och önskemål genom att överskrida avtalen då detta krävs. I båda fallen reproduceras dock upphandlingens marknadsrationalitet.

\section{Referenser}

Almquist, R. \& O. Högberg (2008) "Ten years of CCT. What are the experiences? The example of the City of Stockholm", Kunnallistieteellinen aikakauskirja 36 (2):181-199.

Andersson, C., M. Erlandsson \& G. Sundström (2017) Marknadsstaten. Om vad den svenska staten gör med marknaderna - och marknaderna med staten. Stockholm: Liber.

Barraket, J., R. Keast \& C. Furneaux (red.) (2015) Social procurement and new public governance. New York: Routledge. https://doi.org/10.4324/9780203797532

Bay, U. (2019) "Neoliberalism as an art of governance. Reflecting on techniques for securing life through direct social work practice", European Journal of Social Work 22 (2):201-211. https://doi.org/10.1080/13691457.2018.1530640

Bečević, Z. (2015) Utsatthetens röster. Stockholm: Boréa.

Birk, R.H. (2018) ”Making responsible residents. On 'responsibilization' within local community work in marginalized residential areas in Denmark", The Sociological Review 66 (3):608-622. https://doi.org/10.1177\%2F0038026117738148

Boréus, K. (1994) Högervåg. Stockholm: Tiden. 
Chandler, J., L. Bell., E. Berg \& J. Barry (2015) "Social work in movement. Marketisation, differentiation and managerial performativity in Sweden and England", International Journal of Social Work and Human Services Practice 3 (3):109-117. https://doi.org/10.13189/ijrh.2015.030302

Chambon, A.S., A. Irving \& L. Epstein (red.) (1999) Reading Foucault for social work. New York: Colombia University Press.

Dahlstedt, M. \& P. Lalander (red.) (2018) Manifest-för ett socialt arbete i tiden. Lund: Studentlitteratur.

Dahlstedt, M. \& A. Fejes (red.) (2019) Neoliberalism and market forces in education. Lessons from Sweden. London: Routledge. https://doi.org/10.4324/9780429470530

Ferrera, M. (2008) "The European welfare state. Golden Achievements, silver Prospects", West European Politics 31 (1-2):82-107. https://doi.org/10.1080/01402380701833731

Flyvbjerg, B. (2006) "Five misunderstandings about case-study research", Qualitative Inquiry 12 (2):219-245. https://doi.org/10.1177/1077800405284363

Forkby, T. \& S. Höjer (2008) "Ritual eller strategi - upphandlingar och ramavtal inom den sociala ungdomsvården", Socialvetenskaplig tidskrift 15 (2):115-134. https://doi. org/10.3384/svt.2008.15.2.2578

Foucault, M. (1980) Power/knowledge. New York: Pantheon.

Foucault, M. (1982) "The subject and power", Critical Inquiry 8 (4):777-795 https:// doi.org/10.1086/448181

Garsten, C. \& K. Jacobsson (red.) (2004) Learning to be employable. Basingstoke: Palgrave Macmillan.

Harris, J. (2003) The social work business. London: Routledge. https://doi. org/10.4324/9780203465004

Harris, J. (2014) "(Against) neoliberal social work", Critical and Radical Social Work 2 (1):7-22. https://doi.org/10.1332/204986014x13912564145528

Hartman, L. (2011) Konkurrensens konsekvenser. Vad händer med svensk välfärd? Stockholm: SNS.

Hjärpe, T. (2020) Mätning och motstånd. Sifferstyrning i socialtjänstens vardag. Lund: Lunds universitet.

Holmqvist, D., A. Fejes \& E. Nylander (2021) "Auctioning out education. On exogenous privatisation through public procurement", European Educational Research Journal 20 (1):102-117. https://doi.org/10.1177/1474904120953281

Holstein, J.A. (1992) "Producing people. Descriptive practise in human service work", Current Research on Occupations and Professions 7:23-39.

Härnbro, S. (2019) "Fabricating the motivated client. Problematising the market of social work in Sweden", Critical and Radical Social Work 7 (2):189-202. https://doi. org/10.1332/204986019x15544728070396

Härnbro, S. (2021) "In the name of motivation. The procurement of social work and its technologies of self and power". Opublicerat manuskript.

Höjer, S. \& T. Forkby (2011) "Care for sale. The influence of new public management in child protection in Sweden", British Journal of Social Work 41 (1):93-110. https:// doi.org/10.1093/bjsw/bcq053 
Isaksson, D., P. Blomqvist \& U. Winblad (2018) "Privatization of social care delivery - how can contracts be specified?", Public Management Review 20 (11):1643-1662. https://doi.org/10.1080/14719037.2017.1417465

Juhila, K., S. Raitakari \& C. Hall (red.) (2017) Responsibilisation at the margins of welfare services. Abingdon: Routledge. https://doi.org/10.4324/9781315681757

Jönsson, J. (2019) "Servants of a 'sinking titanic' or actors of change? Contested identities of social workers in Sweden", European Journal of Social Work 22 (2):212-224. https://doi.org/10.1080/13691457.2018.1529659

Katzin, M. (2020) Taking care of business. A study of the governing of care choice systems in Swedish home care. Lund: Lunds universitet.

Larsson, B., M. Letell \& H. Thörn (red.) (2012) Transformations of the Swedish welfare state. From social engineering to governance? Basingstoke: Palgrave Macmillan. https://doi.org/10.1057/9780230363953

Lauri, M. (2016) Narratives of governing. Rationalization, responsibility and resistance in social work. Umeå: Umeå universitet.

Lauri, M. (2019) "Motivational interviewing as governmentality. Shaping victims of men's violence into responsible subjects?", NORA - Nordic Journal of Feminist and Gender Research 27 (2):112-124. https://doi.org/10.1080/08038740.2019.1588374

Lindahl, R. (2019) Socialsekreteraren och det familjehemsplacerade barnet. Om relationen, erkännandet och de institutionella förutsättningarna. Örebro: Örebro universitet.

Lindahl Toftegaard, E. (2018) Offentlig upphandling. LOU och upphandlingsprocessen. Lund: Studentlitteratur.

Lunander, A. \& A. Andersson (2004) Metoder vid utvärdering av pris och kvalitet i offentlig upphandling. En inventering och analys av utvärderingsmodeller inom offentlig upphandling. Stockholm: Konkurrensverket.

Martinell Barfoed, E. (2014) "Standardiserad interaktion - en utmaning för socialt arbete", Socialvetenskaplig tidskrift 21 (1):4-23. https://doi.org/10.3384/ svt.2014.21.1.2427

Moberg, L. (2017) Marketization in Swedish eldercare. Implications for users, professionals, and the state. Uppsala: Uppsala universitet.

Moffatt, K. (1999) "Surveillance and government of the welfare recipient", 219-245 i A.S. Chambon, A. Irving. \& L. Epstein (red.) Reading Foucault for social work. New York: Colombia University Press.

Pedersen, K. (2019) Upphandlingens grunder. En introduktion till offentlig upphandling och upphandling i försörjningssektorerna. Stockholm: Jure.

Ruthström, B. \& H. Svärdman (red.) (2011) Åtta visioner om trygghet. Socialförsäkring i förändring. Stockholm: Premiss.

Rönnberg, L., U. Strandberg., E. Wihlborg \& U. Winblad (red.) (2013). När förvaltning blir business. Marknadiseringens utmaningar för demokratin och välfärdsstaten. Linköping: Linköping University Electronic Press.

Sallnäs, M. \& S. Wiklund (red.) (2018) Socialtjänstmarknaden. Om marknadsorientering och konkurrensutsättning av individ-och familjeomsorgen. Stockholm: Liber.

Scourfield, P. (2007) "Social care and the modern citizen. Client, consumer, service 
user, manager and entrepreneur", The British Journal of Social Work 37 (1):107-122. https://doi.org/10.1093/bjsw/bch346

Skillmark, M. \& L. Oscarsson (2020) "Applying standardisation tools in social work practice from the perspectives of social workers, managers, and politicians. A Swedish case study", European Journal of Social Work 23 (2):265-276 https:/doi.org/1 0.1080/13691457.2018.1540409

Stenius, K. \& J. Storbjörk (2020) "Balancing welfare and market logics. Procurement regulations for social and health services in four Nordic welfare states", Nordic Studies on Alcohol and Drugs 37 (1):6-31. https://doi.org/10.1177/1455072519886094

Stolt, R., P. Blomqvist \& U. Winblad (2011) "Privatization of social services. Quality differences in Swedish elderly care", Social Science \& Medicine 72 (4):560-567. https://doi.org/10.1016/j.socscimed.2010.11.012

Szebehely, M. (2011) "Insatser för äldre och funktionshindrade i privat regi", 215-257 i L. Hartman (red.) Konkurrensens konsekvenser. Vad händer med svensk välfärd? Stockholm: SNS.

Upphandlingsmyndigheten och Konkurrensverket (2020) Statistik om offentlig upphandling 2020. Stockholm: Upphandlingsmyndigheten och Konkurrensverket.

Utredningen Framtidens socialtjänst (2020) Hållbar socialtjänst. En ny socialtjänstlag. SOU 2020:47. Stockholm: Norstedts Juridik.

Vitus, K. (2017) "Policy and identity change in youth social work. From social-interventionist to neoliberal policy paradigms", Journal of Social Work 17 (4):470-490. https://doi.org/10.1177/1468017316648636

Wetherell, M. (2004) "Racism and the analysis of cultural resources in interviews", 11-30 i H. van den Berg, M. Wetherell \& H. Houtkoop-Steenstra (red.) Analyzing race talk. Multidisciplinary perspectives on the research interview. Cambridge: Cambridge University Press. https://doi.org/10.1017/cbo9780511489792

Wiklund, S. (2005) "Social barnavård i nya former. Om marknadsorientering inom barnavårdsarbetet", Socialvetenskaplig tidskrift 12 (2-3):149-168. https://doi. org/10.3384/svt.2005.12.2-3.2624

Wiklund, S. (2011) "Individ- och familjeomsorgens välfärdstjänster", 111-146 i L. Hartman (red.) Konkurrensens konsekvenser. Vad händer med svensk välfärd? Stockholm: SNS. 


\section{Författarpresentation}

Simon Härnbro är doktorand inom socialt arbete. Hans avhandlingsprojekt kretsar kring marknadsorientering inom socialtjänsten, med fokus på upphandling och klientskapande inom utförande socialt arbete.

Marcus Herz är docent i socialt arbete vid Göteborgs universitet. Hans forskning och tidigare publikationer handlar om socialt arbete, migration, kön, maskulinitet och ungdomar.

Magnus Dahlstedt är professor i socialt arbete vid Linköpings universitet. Hans forskning rör frågor om välfärd och medborgarskapande, med särskilt fokus på unga, inkludering och exkludering $\mathrm{i}$ en samtid präglad av marknadsorientering och internationell migration.

\section{Kontaktuppgifter}

Simon Härnbro

Institutionen för kultur och samhälle, avdelningen socialt arbete

Linköpings universitet, 58183 Linköping

simon.harnbro@liu.se 